\title{
HISTORICAL AND CURRENT DISTRIBUTION OF SEGETAL WEED LOLIUM TEMULENTUM L. IN SLOVAKIA
}

\author{
Pavol ELIÁŠ jun. ${ }^{1}$, Mária HAJNALOVÁ ${ }^{2}$ \& Mariana ELIÁŠOVÁ ${ }^{3}$
}

\begin{abstract}
The past and present distribution of a rare segetal weed darnel ryegrass (Lolium temulentum) in Slovakia is presented. The study is based on revision of herbarium specimens from 12 herbaria and a field survey carried out during 2005-2009. Altogether, 95 localities of this species were recorded in Slovakia. Prior to 1950 it was a relatively abundant taxon recorded and confirmed at 75 localities throughout the country, but then it began to vanish. Only 20 localities were recorded between 1950 and 1990, and in 1999 it was evaluated as extinct from Flora of Slovakia. However, since 2005 new occurrences were discovered in northern Slovakia (Orava and Pieniny regions), and its status had been changed. Results of the study are summarised in the map of historical and actual species distribution.
\end{abstract}

Key words: Lolium temulentum, distribution, rare weeds, Slovakia.

\section{Izvleček}

V članku je predstavljena nekdanja in današnja razširjenost segetalnega plevela omotne ljulke (Lolium temulentum) na Slovaškem. Raziskava temelji na reviziji herbarijskih primerkov iz 12 herbarijev in terenskega pregleda v letih od 2005 do 2009. Na Slovaškem smo zabeležili 95 rastišč. Pred letom 1950 je bila omotna ljulka razmeroma pogosta, ugotovili smo namreč 75 rastišč po celotni državi, po tem letu pa je začela izginjati. Potrdili smo samo 20 rastišč med letoma 1950 in 1990, leta 1999 pa je bila vrsta ocenjena kot izumrla v flori Slovaške. Vendar smo po letu 2005 odkrili nova nahajališča v severni Slovaški (območji Orava in Pieniny) in tako spremenili njen status. Rezultati raziskave so prikazani na karti nekdanje in sedanje razširjenosti vrste.

Ključne besede: Lolium temulentum, razširjenost, redki pleveli, Slovaška.

\section{INTRODUCTION}

Lolium temulentum (Fig. 1) is one of the three weedy species (another two are L. remotum and L. persicum) within the relatively small genus $L o$ lium including only five species in Europe and eight taxa in the whole world (Terrell 1968, Conert 1996). This could be changed in future because some researchers have suggested that some of the Festuca species (e.g. Festuca pratensis) may be more correctly classified as a Lolium (Darbyshire 1993, Stammers et al. 1995).

The origin of Lolium temulentum remains still open. Many authors assume the original occurrence of the species in the Mediterranean and southwest Asia from where it spread as a weed of cereals to all of Europe, Central and Southern Africa, eastern Asia, Australia, New Zealand and America (Terrell 1968, Holm et al. 1977, Conert 1996). It is often said that it spread from the Middle East to Europe as a weed in fields of Secale

\footnotetext{
${ }^{1}$ Department of Botany, Slovak University of Agriculture, Tr. A. Hlinku 2, SK-949 76 Nitra, Slovakia, pelias@afnet. uniag.sk

${ }^{2}$ Department of Archaeology, Constantine the Philosopher University, Hodžova 1, SK-949 74 Nitra, Slovakia, mhajnalova@ukf.sk

${ }^{3}$ Department of Ecology, Slovak University of Agriculture, Mariánska 10, SK-949 76 Nitra, Slovakia, mariana. eliasova@uniag.sk
} 


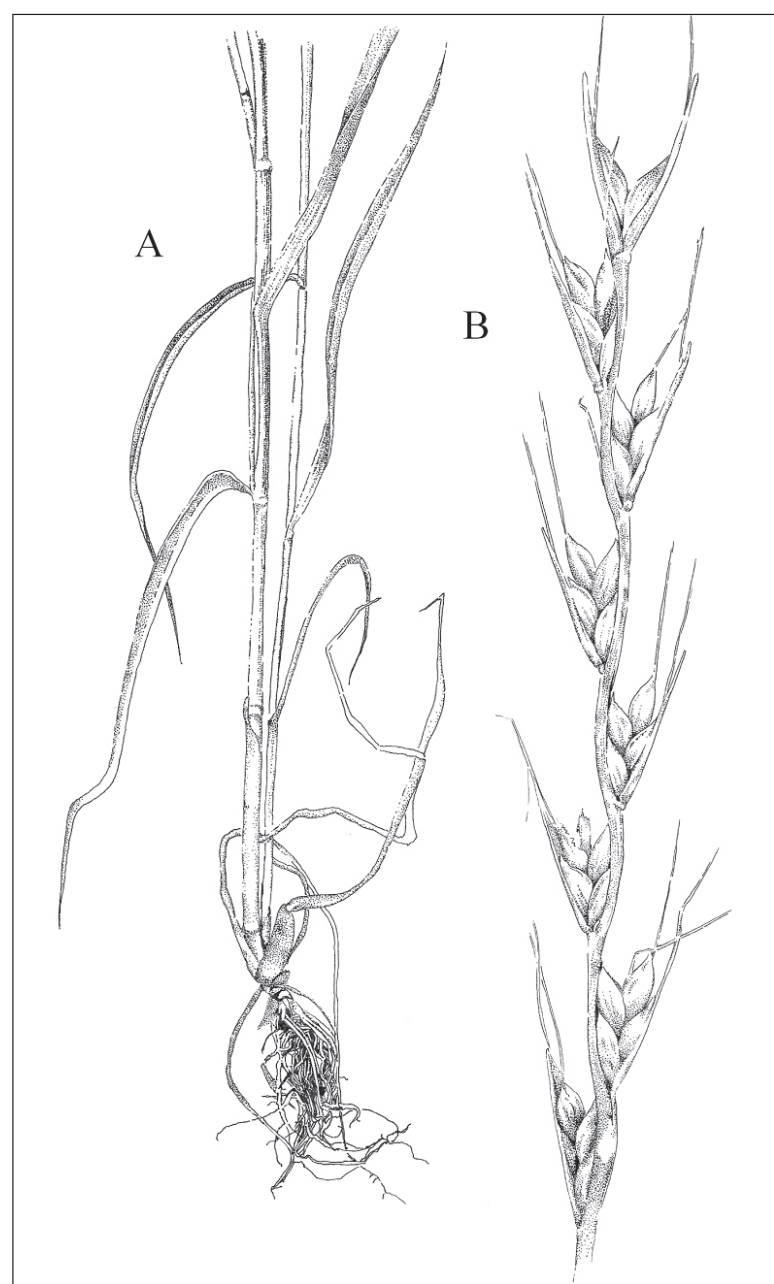

Figure 1: Growth habit of Lolium temulentum: A - culm with roots, B - inflorescence, ear with spikelets (drawn by Peter Čepček, 2008).

Slika 1: Rastne značilnosti Lolium temulentum: A - steblo s koreninami, B - socvetje, klaski z ogrinjalnimi plevami (slika Peter Čepček, 2008).

cereale and Avena sativa. This is incorrect. Both rye and oat are secondary domesticates, thus they were not domesticated in the Fertile Crescent from wild progenitors. Firstly they were only weeds of the arable fields and only much later on recognized and taken into cultivation in the temperate periphery of the Old World (Zohary $\&$ Hopf 2002). Both rye and oat came to central and northern Europe as weeds of other cereals - Triticum monococcum, T. dicoccum and Hordeum vulgare. Even though their kernels sporadically occur in the archaeological assemblages since the Neolithic, the first signs of rye cultivation in Central Europe are not prior to the Bronze Age
(Küster 2000), and of oat for the late Iron Age or Roman period (Zohary \& Hopf 2002). They both are widespread in Europe since the early Middle Ages ( $6^{\text {th }}$ century AD) until modern Times.

In Central Europe, Lolium temulentum is regarded as an archeophyte (Soó 1970, Conert 1996, Halada 1997, Kästner et al. 2001) (Fig. 2). Archaeobotanical data support this categorisation. The earliest find of charred Lolium temulentum kernels, mostly associated with charred cereal assemblages, occurs on archaeological sites in the Mediterranean (at Cyprus it dates to early Neolithic PPNB 8700-6200 BC; Wilcox 2001) and the Middle East (Jordan, Neolithic ca 62005000 BC; Neef 2001). From the period between the 5000-3000 BC it is known from sites in Egypt (Fahmy 2003, van Zeist et al. 2003) and Italy (Costantini 2002). Later in prehistory (between $4000 \mathrm{BC}$ to the turn of eras) it is found in Austria, Denmark, Egypt, France, Germany, Greece, Israel, Italy and Turkey (Kroll 2009). It reaches northern Europe in the $2^{\text {nd }}$ millennium $\mathrm{BC}$ at the latest, where it was found in Alvastra - a Neolithic site in Sweden (Göransson 2001). In the Middle Ages its occurrence in Europe rises, even if it never is a very abundant seed in the charred assemblages. (Note: please keep in mind that while the $3^{\text {rd }}$ and $2^{\text {nd }}$ millennium BC in Sweden is connected with the Neolithic - first farmers and prior this period there were only hunter-gatherers, while in the Mediterranean there already were Bronze Age Palaces and farming had been established for over 3 millennia).

From the territory of Slovakia, there is only one archaeological record of Lolium temulentum. It comes from the site of Nitriansky Hradok a fortified early Bronze Age tell (late $3^{\text {rd }}$ early $2^{\text {nd }}$ millennium BC; Kühn 1981). In the neighbouring Czech Republic it has been recorded on one site from the Bronze Age (Kühn 1981), two from the Hallstatt period (750-500/450 BC; Kühn 1980, Opravil 1978), and one from the High Middle Ages (13 ${ }^{\text {th }}-15^{\text {th }}$ cent. AD; Kühn 1977); in Austria it has been found in Stillfried, a late Bronze Age hillfort (ca 900 BC; Kohler-Schneider 2001) and in Poland it is known from the late Iron Age (300 BC-200 AD; Lityńska-Zając 1997) and the medieval period $\left(11^{\text {th }}-12^{\text {th }}\right.$ cent. AD; Polcyn 2000).

The species is usually mentioned as a characteristic member of segetal vegetation of classes Stellarietea mediae (Mucina 1993, Conert 1996, Kästner et al. 2001, Kropáč 2006) or Secalinetea 




Figure 2: Area of distribution of Lolium temulentum L. (Hultén and Fries, 1986).

Slika 2: Območje razširjenosti vrste Lolium temulentum (Hultén in Fries, 1986).

(Oberdorfer 1983). In Slovakia it was regarded as a diagnostic taxon of class Stellarietea mediae, subclass Violenea arvensis (Passarge \& Jurko 1975, Jarolímek et al. 1997, Májeková \& Zaliberová 2007), but the species was sporadically also found in ruderal vegetation of Atriplici-Chenopodietalia albi (Passarge \& Jurko 1975, Eliáš 1977, Mochnacký 1987).

The seeds of Lolium temulentum are very nutritious and used to be used for making bread (Moerman 1998). However, it is not advisable to eat it because sometimes it can be infected with an endophytic fungus Endoconidium temulentum, which is assumed to be the source of the toxic pyrrolizidine alkaloids (Dannhardt \& Steindl 1985, Baloun et al. 1989). As the ancient and traditional agricultural practices could not separate seeds of L. temulentum from those of wheat or rye, in the past the infected seeds often used to poison the flour (Terrell 1968). This fungal infection, called ergot, causes hallucinations in small doses and can, in larger quantities, cause severe damage to the nervous system (Chakravarty 1976). Slovenian ethnical groups living in western Hungary reportedly mixed the seeds of Lolium temulentum with those of barley to enhance the narcotic effects of beer. Lolium temulentum was already mentioned in the Bible, in some regions it was so abundant that it devastated the total yields of cereals, and became the symbol of disaster (Pinke \& Pál 2005).

Until a few decades back, L. temulentum had a significant impact as a weed in Europe, but due to enhanced seed cleaning techniques and herbicide application the distribution area of the species has largely decreased (Humphries 1980, Hubbard \& Hubbard 1984, Kästner et al. 2001). Due to its massive retirement, the species was in- 
cluded into the Red lists in some Central European countries (northern Croatia: Hulina 2005, Slovakia: Feráková et al. 2001, Eliáš jun. et al. 2007), and in many other countries of this region it is missing or extinct (Austria: Niklfeld and SchrattEhrendorfer 1999, Czech Republic: Procházka 2001, Hungary: Király 2007).

In Slovakia occurrence of Lolium temulentum has not yet been studied in detail. Thus, the present paper aims to reconstruct its historical and recent distribution.

\section{MATERIAL AND METHODS}

Analyses of herbarium specimens and the field survey were carried out in the period of 20052009. The data concerning the past and more recent distribution of the species were obtained from herbariums of BP, BRA, BRNU, BRNM, NI, PMK, PR, PRC, SAV, SMBB, SLO and ZV. Herbarium specimens collected during field surveys are stored in herbarium NI. Herbarium abbreviations are according to Holmgren et al.
(1990) and Vozárová \& Sutorý (2001). The results are presented on the point map. The grid of the map follows one that was described by Niklfeld (1971). The abbreviations of papers published before 1956 cited in the Appendix follow Futák \& Domin (1960). More recent publications are cited in short form. Phytogeographical divisions of Futák (1980) are also used.

\section{RESULTS AND DISCUSSION}

Lolium temulentum was once distributed almost throughout the whole territory of Slovakia. We found the herbarium specimens and literature data from 95 localities (Fig. 3, Appendix). It is clear that it was a relatively common arable weed up to about the mid- $20^{\text {th }}$ century; 75 localities were found from this period. This trend is also recorded in some of the earlier works (see e.g. Holuby 1871, Dostál 1950, and Kupčok 1956). However, the massive retirement of the species was caused by large changes in agriculture between 1950 and 1990 (collectivization, application of pesticides,

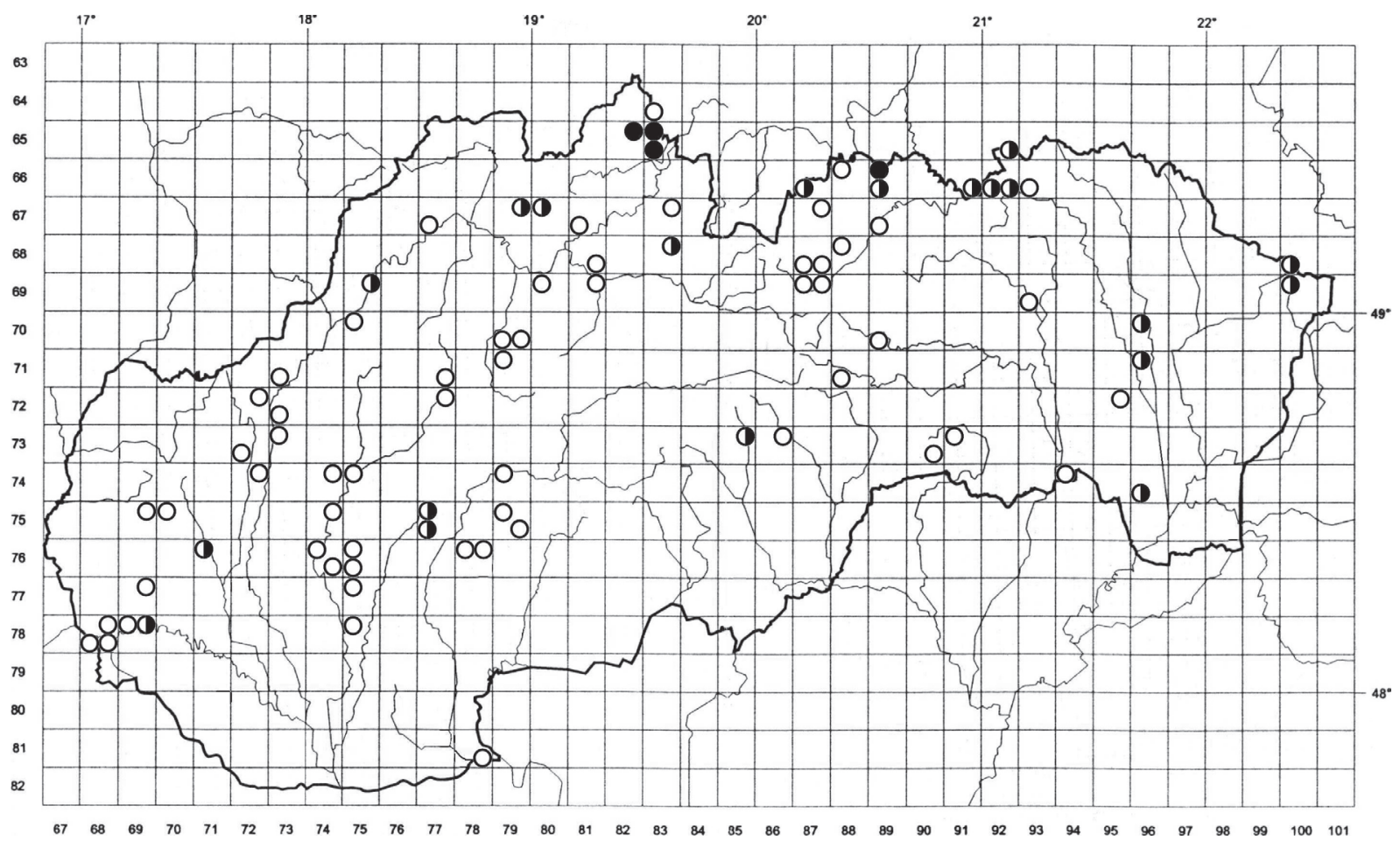

Figure 3: Historical and recent distribution of Lolium temulentum in Slovakia: O - before 1950, O - 1950-1999, - 2000 onwards.

Slika 3: Historična in recentna razširjenost vrste Lolium temulentum na Slovaškem: O - pred 1950, O - 1950-1999, - po 2000. 
new seed cleaning practices etc.). For this period the species was confirmed only at 20 localities and it has become rare, the last locality being found in 1990 (Mered'a sen. 2000). Similar disappearing of weed species under the pressure of intensive agriculture in Slovakia was published, for example, for Agrostemma githago and Bupleurum rotundifolium (Šourková 1981, David \& Dudich 1997).

Under the influence of the mentioned modern farming methods of crop production, Lolium temulentum was pushed away from fields, and it has been more often found on ruderal sites (e.g. Svobodová 1974, Eliáš 1977). Finally, at the end of the last century it was marked as extinct (Holub 1999).

Nevertheless, since 2000 occurrence of the species was de novo documented at five localities. Firstly L. temulentum was confirmed by the first author on two sites near the village of Lesnica (northern Slovakia, Pieniny region) in 2005 (Eliáš jun. 2006). One year later Májeková \& Zaliberová (2007) discovered it at three localities in the surroundings of Rabča and Zubrohlava (north-western Slovakia, Orava region). The occurrence of the species near Lesnica was repeatedly confirmed in 2007 (Kĺč \& Kunštárová 2007). Therefore, the species is now in Slovakia regarded as critically endangered (Feráková et al. 2001, Eliáš jun. 2006).

There are two possibilities which could cause the recent occurrence of Lolium temulentum in Slovakia: a) the species could have sporadically survived in small privately owned and traditionally farmed fields to the present time but was overlooked by botanists; b) present occurrence of the species could be caused by the transfer of oat and rye seed corn from Poland.

The former presumption is based on the relatively low intensity of current arable weed flora research in Slovakia. Intensive research into Slovak segetal vegetation started in the 1970s, continued in the 1980s and culminated in the 1990s with the publication of the monograph on synanthropic vegetation of the country (Jarolímek et al. 1997, Mochnacký 2000). Recently, research on segetal vegetation has been weak and only some partial works have been published (e.g. Májeková 2004, Zaliberová \& Májeková 2004, Májeková \& Zaliberová 2005, Mochnacký 2005). Therefore, during last decade only a few rare segetal weeds, such as Aphanes arvensis, Bromus secalinus, Conringia orientalis, Galium tricornutum or Scandix pectin-veneris, were rediscovered and confirmed in the field for Slovak flora (Ripka \& Mered'a 1999, Zaliberová \& Urbanová 2000, Devánová et al. 2006, Eliáš jun. 2007). This deficient research activity could be a reason why L. temulentum has been currently overlooked in Slovakia.

Májeková \& Zaliberová (2007), mention that actual species occurrence can be connected with the transfer of oat and rye seed corn from Poland, where the species is still relatively abundant (Zajac \& Zajac 2001). This possibility is supported by the current presence of the species only in northwestern and north Slovakia in the region on the border with Poland. In Poland, the collectivization of agriculture did not take place, and the small land-holders usually dispose with only unpowerful seed cleaning technologies (Sokolovsky 1990). The size and weight of Lolium temulentum grains are similar to those of cereal grains, so that these seeds cannot be separated from cereal grains by winnowing or sieving (Tominaga \& Yamasue 2004). Awns of darnel ryegrass serve as a tool for anthropogenic dispersal. The morphology of awned darnel grains resembles emmer wheat grains, and awnless darnel grains resemble freethreshing wheat grains. Thus, grain mimicry controls the close association of the two forms of darnel with the wheat species. The lack of an awn itself functions for darnel grain as a dispersal mechanism in free-threshing wheat cultivation systems compared with other wild grass species (Tominaga \& Fujimoto 2004).

Although the species had been proclaimed extinct, this pessimistic prediction was not confirmed and the species still occurs in Slovakia. We hope that the rediscovery of darnel ryegrass will promote the acceleration of weed research in Slovakia.

\section{AGKNOWLEDGEMENTS}

We thank J. Májeková (Bratislava, Slovakia) and P. Mered'a sen. (Nová Dubnica, Slovakia) for their comments on the historical and recent distribution of the species. We are indebted to M. Ducháček (Průhonice, Czech Republic), D. Hrčka (Odolena Voda, Czech Republic), V. Kerényi-Nagy (Budapest, Hungary) and R. Šuvada (Brzotín, Slovakia) for the herbarium data excerption. The research was funded from the projects VEGA No. 1/0086/08 and 1/0530/08. 


\section{REFERENCES}

Baloun, J., Jahodář, L., Leifertová, I. \& Štípek, S. 1989: Rostliny způsobující otravy a alergie. Avicenum, Praha, pp. 235.

Conert, H. J. 1996: Lolium. In: Hegi, G. (ed.), Illustrierte Flora von Mitteleuropa 1/3, Lieferung 8/9. Parey, Berlin, pp. 633-648.

Costantini, L. 2002: Italia centro-meridionale. In: Forni, G. \& Marcone, A. (eds.): Storia dell'agricoltura italiana. 1 L'età antica 1. Preistoria. Firenze, pp. 221-233.

Dannhardt, G. \& Steindl, L. 1985: Alkaloids of Lolium temulentum: Isolation, Identification and Pharmacological Activity. Planta Medica (Stuttgart), pp. 212-214.

Darbyshire, S. J. 1993: Realignment of Festuca subspecies Schedondrus with the genus Lolium (Poaceae). Novon 3: 239-243.

David, S. \& Dudich, A. 1997: Příspěvek k rozšíření druhu Agrostemma githago L. (Dianthaceae) na Slovensku. Bulletin Slovenskej botanickej spoločnosti 19: 34-41.

Devánová, K., Eliáš, P. ml. \& Kresáňová, K. 2006: Nové poznatky o výskyte ohrozených druhov agrocenóz v CHKO Biele Karpaty. Bulletin Slovenskej botanickej spoločnosti, 28 Suppl. 1: 103-112.

Deyl, M. 1964: Plevele polí a zahrad. Nakladatelství Československé akademie věd, Praha, 390 pp.

Dostál, J. 1950: Květena ČSR. Př́rodovědné nakladatelství, Praha, 269 pp.

Eliáš, P. 1977: Jarné efemérne ruderálne spoločenstvá Trnavy. Biológia, 32 (1): 11-23.

Eliáš, P. ml. 2006: Mätonoh mámivý (Lolium temulentum) stále rastie v Pieninách (severné Slovensko). Bulletin Slovenskej botanickej spoločnosti, 28: 77-79.

Eliáš, P. jun. 2007: Rye brome (Bromus secalinus) in Slovakia. In: Eliáš, P. jun. (ed.), Threatened weedy plant species. Book of proceedings from the international conference, Slovak University of Agriculture, Nitra, pp. 68-71.

Eliáš, P. jun., Eliáš, P. sen. \& Baranec, T. 2007: The New red list of Slovak endangered weeds. In: Eliáš, P. jun. (ed.), Threatened weedy plant species. Book of proceedings from the international conference, Slovak University of Agriculture, Nitra, p. 23-28.

Fahmy, A. G. 2003: Palaeoethnobotanical studies of Egyptian Predynapstic cemeteries: new dimensions and contributions. In: Neumann,
K., Butler, A. \& Kahlheber, S. (eds.): Food, fuel and fields. Progress in African archaeobotany. Acta Praehistorica 15, pp. 95-106.

Feráková, V., Maglocký, Š. \& Marhold, K. 2001: Červený zoznam paprad'orastov a semenných rastlín. In: Baláž, D., Marhold, K. \& Urban, P. (eds.): Červený zoznam rastlín a živočíchov Slovenska. Ochrana prírody, Suppl. 20: 44-76.

Futák, J. 1980: Fytogeografické členenie SSR (1: 1 000 000). In: Mazúr, E. (ed.): Atlas Slovenskej socialistickej republiky. SAV, Bratislava, p. 88.

Futák, J. \& Domin, K. 1960: Bibliografia k flóre ČSR. Vyd. SAV, Bratislava, 884 pp.

Göransson, H. 2001: Alvastra pile dwelling - a 5000-year-old byre? In: Viklund, K. (ed.): Nordic archaeobotany - NAG 2000 in Umeå. Archaeology and Environment 15: 67-84.

Halada, L. 1997: Archeofyty flóry Slovenska. Bulletin Slovenskej Botanickej Spoločnosti, 19: 129-136.

Holm, L. G., Plucknett, D. L., Pancho, J. V. \& Herberger, J. P. 1977: The world's worst weeds: distribution and biology. University Press of Hawaii, Honolulu, 609 pp.

Holmgren P. K., Holmgren N. H. \& Barnett L. C. (eds.) 1990: Index Herbariorum. Vol. 1: The herbaria of the World, Ed. 8. New York, $693 \mathrm{pp}$

Holuby, J. L. 1871: Kvetna Javoriny nad Lubinou. Letopisy Matice Slovenskej 8: 5-43.

Holub, J. 1999: Čierny zoznam kveteny Slovenskej republiky. In: Čeřovský, J. et al. (eds.): Červená kniha ohrozených a vzácnych rastlín a živočíchov SR a ČR 5. Vyššie rastliny. Príroda, Bratislava, p. 414.

Hubbard, C. E. \& Hubbard, J. C. E. 1984: Grasses, A guide to their structure, identification, uses, and distribution in the British Isles. Pelican Books, Harmonsworth, 476 pp.

Hulina, N. 2005: List of Threatened Weeds in the Continental Part of Croatia and their Possible Conservation. Agriculturae Conspectus Scientificus 70 (2): 37-42.

Hultén, E. \& Fries, M. 1986: Atlas of North European vascular plants: north of the Tropic of Cancer I. Koeltz Scientific Books, Königstein, $498 \mathrm{pp}$

Humphries, C. J., 1980. Lolium. In: Tutin, T. G., Heywood, V. H., Burges, N. A. et al. (eds.), Flora Europaea Vol. 5. Cambridge University Press, Cambridge, p. 153-154.

Chakravarty, H. L. 1976: The Plant Wealth of Iraq. A dictionary of Economic plants. Vol. 1. 
Ministry of Agriculture and Agrarian Reforms, Bagdad, 359 pp.

Jarolímek, I., Zaliberová, M., Mucina, L. \& Mochnacký, S. 1997: Rastlinné spoločenstvá Slovenska 2. Synantropná vegetácia. Veda, Bratislava, 416 pp.

Kästner, A., Jäger, E. J. \& Schubert, R. 2001: Handbuch der Segetalpflanzen Mitteleuropas. Springer, Wien \& New York, 609 pp.

Király, G. (ed.) 2007: Vörös Lista. A magyarországi edényes flóra veszélyeztetett fajai. Saját kiadás, Sopron, $73 \mathrm{pp}$.

Kíč, V. \& Kunštárová, V. 2007: Mapovanie burín na políčkach Pienin a Zamaguria (severné Slovensko). Multifunkční obhospodařování a využívání travních porostů v LFA. 1. vyd. Výzkumný ústav pro chov skotu, Rapotín, pp. 184-190.

Kohler-Schneider, M. 2001: Verkohlte Kulturund Wildpflanzenreste aus Stillfried an der March als Spiegel spätbronzezeitlicher Landwirtschaft im Weinviertel, Niederösterreich. Österreichische Akademie der Wissenschaften, Wien, 226 pp.

Kroll, H. 2009: Literature on archaeological remains of cultivated plants 1981-2004. http:// www.archaeobotany.de/database.html (accessed $11^{\text {th }}$ November 2009).

Kropáč, Z. 2006: Segetal vegetation in the Czech Republic: synthesis and syntaxonomical revision. Preslia 78: 123-209.

Kupčok, S. T. 1956: Príspevok k poznaniu flóry okolia Banskej Štiavnice a Pukanca. Biologické práce SAV 2 (9): 1-62.

Kühn, F. 1977: Obilí z hradu Rokštejn u Luk nad Jihlavou (odr. Jihlava). Přehled výzkumů 1975. Archeologický ústav ČSAV, Brno, pp. 93-94.

Kühn, F. 1980: Botanický rozbor obilí z halštatské doby z Rajhradu (okr. Brno venkov). Přehled výzkumů 1977. Archeologický ústav ČSAV, Brno, pp. 3-46.

Kühn, F. 1981. Rozbory nálezů polních plodin. Přehled výzkumů 1979. Archeologický ústav ČSAV, Brno, pp.75-79.

Küster, H. 2000: Rye. In: Kiple, K. F. \& Ornelas, K. C. (eds.): Cambridge World History of Food. Cambridge University Press, Cambridge, pp. 149-152.

Lityńska-Zając, M. 1997: Rośinność i gospodarka rolna w okresie rzymskim. Studjum archeobotaniczne. Instytut Archeologii i Etnologii PAN, Krakow, 279 pp.
Májeková, J. 2004: Veronicetum trilobae-triphyllidi Slavnić 1951 - jarné spoločenstvo polí a úhorov na Borskej nížine po 50-tich rokoch. Bulletin Slovenskej botanickej spoločnosti, 26 Suppl. 10: 57-62.

Májeková, J. \& Zaliberová, M. 2005. The occurrence and distribution of rare and endangered plant species in segetal communities in the Borská nížina Lowland. Thaiszia - Journal of Botany 15 Suppl. 1: 129-142.

Májeková, J. \& Zaliberová, M. 2007: Lolium temulentum (mätonoh mámivý) na Orave. Bulletin Slovenskej botanickej spoločnosti, 29: 92-96.

Mered'a, P. sen. 2000. Lolium temulentum. In: Mráz, P. (ed.), Floristicky zaujímavejšie nálezy. Bulletin Slovenskej botanickej spoločnosti, 22: 170 .

Moerman, D. E. 1998: Native American Ethnobotany. Timber Press, Portland, 927 pp.

Mochnacký, S. 1987: Burinové spoločenstvá v agrocenózach Východoslovenskej nížiny. PhD. Thesis, 204 pp.

Mochnacký, S. 2000: Syntaxonomy of segetal communities of Slovakia. Thaiszia - Journal of Botany 9: 149-204.

Mochnacký, S. 2005: Cereal stubble communities in the East Slovakia. Thaiszia - Journal of Botany 15 Suppl. 1: 45-51.

Neef, R. 2001: The plant remains. In: Kafafi, Z.A. (ed.): Jeben Abu Thawwab (Er-Rumman), Central Jordan. The late Neolithic and early Bronze Age I occupations. Bibliotheca Neolitica Asiae meridionalis et occidentalis. Ex oriente, Berlin, pp. 203-209.

Niklfeld, H. 1971: Bericht über die Kartierung der Flora Mitteleuropas. Taxon 20: 545-571.

Niklfeld, H. \& Schratt-Ehrendorfer, L. 1999: Farnund Blütenpflanzen. In: Niklfeld, H. (ed.): Rote Listen gefährdeter Pflanzen Österreichs. Grüne Reihe des Bundesministeriums für Umwelt, Jugend und Familie, Wien 10: 33-152.

Oberdorfer, E. 1983: Secalietea Br.-Bl. 1952. In: Oberdorfer, E. (ed.): Süddeutsche Pflanzengesellschaften. Teil III. ed. 2. Gustav Fischer Verlag, Jena, pp. 15-47.

Opravil, E. 1978: Synantropische Pflanzengesellschaften in der ČSSR - Vorzeit. Acta Botanica Slovaca Academiae Scientiarum Slovaceae A3, pp. 479-490.

Passarge, H. \& Jurko, A. 1975: Über Ackerunkrautgesellschaften im nordslowakischen Bergland. Folia Geobotanica et Phytotaxonomica 10: 225-264. 
Pinke, G. \& Pál, R. 2005: Gyomnövényeink eredete, termőhelye és védelme. Alexandra Kiadó, Pécs, 231 pp.

Polcyn, M. 2000: Uwagi na temat wybranych zbiorowisk roślinnych $\mathrm{w}$ otoczeniu wczesnośredniowiecznego Ostrowa Lednickiego i Giecza. Studie Lednickie 6: 339-350.

Procházka, F. (ed.) 2001: Černý a červený seznam cévnatých rostlin České republiky (stav v roce 2000). Př́roda, 18: 1-166.

Ripka, J. \& Mered'a, P. 1999: Scandix pecten-veneris L. znovunájdený na Slovensku. Bulletin Slovenskej botanickej spoločnosti, Bratislava, 21: 69-72.

Sokolovsky, J. 1990: Peasants and Power: State Autonomy and the Collectivization of Agriculture in Eastern Europe. Westview Press, Boulder, $181 \mathrm{pp}$.

Soó, R. 1970: A magyar flóra és vegetáció rendszertani-növényföldrajzi kézikönyve IV. Akadémiai Kiadó, Budapest, 614 pp.

Stammers, M., Harris, J., Evans, G.M., Hayward, M. D. \& Foster, J. W. 1995: Use of random PCR(RAPD) technology to analyse phylogenetic relationships in the Lolium/Festuca complex. Heredity 74: 19-27.

Svobodová, Z. 1974: Nové nálezy synantropnych druhov na Slovensku. Acta Instituti Botanici Academiae Scientiarum Slovaciae, seria A 1: 101-106.

Šourková, M. 1981: Bupleurum rotundifolium jeho dř́vější a současné rozšíření v Československu. Studie ČSAV 20: 95-97.

Terrell, E. E. 1968: A taxonomic revision of the genus Lolium. Technical Bulletin, United States Department of Agriculture No. 1392, pp. 1-65.

Tominaga, T. \& Fujimoto, T. 2004: Awn of darnel (Lolium temulentum L.) as an anthropogenic dispersal organ: A case study in Malo, southwestern Ethiopia. Weed Biology and Management 4 (4): 218-221.

Tominaga, T. \& Yamasue, Y. 2004: Crop-associated weeds. In: Inderjit, E. (ed.): Weed Biology and Management. Kluwer Academic Publisher, Dortrecht, pp. 43-67.

van Zeist, W. \& de Roller G.J. 2003: An archaeobotanical study of Maadi, a pre-dynastic site in lower Egypt. In: van Zeist, W. (ed.): Reports on archaeobotanical studies in the Old World. Groningen, 167 pp.

Wilcox, G. 2001: Présence des céréales dans le Néolithique précéramique de Shillourokam- bos à Chypre: Résultats de la campagne 1999. Paléoerient 26 (1): 129-135.

Zając, A. \& Zając, M. (eds.) 2001: Distribution Atlas of Vascular Plants in Poland. Institute of Botany, Jagiellonian University, Krakow, 716 pp.

Zaliberová, M. \& Urbanová, V. 2000: Nová lokalita Aphanes arvensis - drobnobyl drobná. Ochrana prírody 18: 51-54.

Zaliberová, M. \& Májeková, J. 2004: Asociácia Cerastio-Ranunculetum sardoi Oberd. ex Vicherek 1968 na poliach a jednoročných úhoroch na Borskej nížine. Bulletin Slovenskej botanickej spoločnosti, 26: 177-183.

Zohary, D. \& Hopf, M. 2002: Domestication of plants in the old world. Third edition. Oxford University Press, Oxford, 316 pp.

\section{APPENDIX}

A list of localities of Lolium temulentum in Slovakia [numbers of phytogeographical regions according to Futák (1980)].

Pannonicum: 1. Chl'aba (Grundl 1860 BRA). 3. Turňa nad Bodvou, Zádielska dolina Valley, 600 m (J. Dostál 1927 PRG). - Hačava, Jelení vrch Hill (Thaisz 1909 PR). 6. Bratislava, part Petržalka (Nábělek 1936 SAV). - Bratislava, road to part Koliba (Dohnány 1938 SLO). - Bratislava, part Mlynské nivy [Mühlau] (Lumnitzer 1791: 49). - Ivanka pri Dunaji, greenhouses of kolchoz (Jasičová 1973 SAV). - Modra (Mergl 1894 SAV). - Svätý Jur (Holuby 1913 PRC). - Pezinok, railway station (Holuby 1916 BRA). - Pezinok, rarely in fields (Holuby 1916 PRG). - Lošonec, in rye (Wiesbauer 1871a: 5). - Trnava (Eliáš, Biológia, vol. 32/1, p. 16-17, 1977). - Nitra - Komjatice Zbehy - Golianovo - Jelenec - Vel'ký Lapáš - Tovarníky - Mýtny Nová Ves - Topol'čany - Vrbové - Pieštany - Prievidza (all data Knapp 1865: 19). - Nové Mesto nad Váhom (Knapp 1. c.; Keller, Math. term.-tud. Közl. 4: 208, 1866). - Streda nad Váhom (Keller l. c.). 8. Vranov nad Toplou, oat field (Nevrlý 1957 BRNM). - Zemplínsky Branč, near the road to Novosad (Mochnacký, PhD. Thesis, p. 204, 1987).

Carpaticum: 9. Haluzice (Holuby sine data BP, BRNU). - Zemianske Podhradie (Holuby 1865 SLO, 1866 BP, BRA, 1872, 1875 BP, BRA, 1880 PRC, 1882, 1884, 1896 BP, 1887 BRA). - Bošáca, 
Bošácka dolina valley (Holuby 1876, 1878, 1884 BP, 1887 BRNU, 1891 BP, 1895 PR, 1898 BRNU, 1901 BP). 10. Plavecké Podhradie, cereal fields (Ptačovský 1929 SAV). 11. Hrádok (Knapp 1791: 49). 12. Jedl'ové Kostol'any, Brezov štál hamlet, ruderal site (Eliáš, Rosalia 1: 118, 1984). 13. Bojnice, 330 m (Knapp 1865: 19; Schidlay 1949 BRA). - Dubnica, in field, $300 \mathrm{~m}$ (Schidlay 1949 BRA). - Kanianka, in oat field, 320-350 m (Domin 1949 ined.). 14a. Vel'ká Lehota, barley field near bus stop (Svobodová 1971 NI and Acta Inst. Bot. Acad. Sci. Slov., ser. A, 1: 101-106, 1974). 14e. Pukanec (Kupčok 1908 BP, PR). - Pukanec, part Teplá Voda (Kupčok 1894 PR). - Královce (Kmet' 1880 BRA). - Krnišov (Kmet' 1876 BRA). - Prenčov (Kmet' 1890 BP; Cserey 1894: 69 and 1897: 25; Hlavaček, Flóra CHKO Štiavnické vrchy, p. 301, 1985). - Antol - Banský Studenec Banská Štiavnica (all data Cserey l.c.). - Banská Štiavnica (Cserey 1892 BRA). - Ladomerská Vieska (Szép 1885 BRA). 15. Tisovec, in fields (Vraný 1926 BRA, PRC; Hendrych, Preslia 27, p. 68, 1955 and Acta Carol., 1968/2, p. 215, 1969). - Revúca (Schidlay 1931 BRA). - Dobšiná (Lengyel 1926, 1928 BP). 19. Skároš (Thaisz 1908 BRA). - Backov (Dorner 1846 BP, 1853 BP). 25. Podhradie (Puchert 1866 SLO). 21b. Belá, western slopes of Sokolie hill, oat field, $560 \mathrm{~m}$ - Terchová, hamlet of Podhorskovci, oat field, $750 \mathrm{~m}$ (both data Štachl, Biológia 25/7, p. 493, 1970). 21c. Blatnica (Textorisová 1890 PRC). 21d. Valaská Dubová (Margittai 1909 PR). - Likavka (Lengyel, Die Flora der vorstlichen Versuchaflächen bei Likavka, p. 10, 1915; Vávra, Prír. Sb. I., p. 264, 1946). - Vel'ké Borové, fields (Szontagh, Verh. Zool-bot. Ges. Wien, vol. 13, p. 1051, 1863; Chrtek et Kř́sa 1971 PR; Chrtek et Krrísa, Acta Univ. Carol. Biol., 1971, p. 48, 1977). 22. Svit, fields near hill of Baba (Bartal, Növ. Közl., no. 2, p. 125, 1903). 23a. Zuberec, 740 m (Scheffer 1928 BP; Kosík et J. Dostál 1928 PRC). 23b. Dolný Smokovec (Czakó 1887 BP). - Nová Lesná (Sztehlo 1876 BP). - Rakúsy (Simonkai 1890 BP). 24. Červený Kláštor, in valley of Dunajec river (Domin 1932 PRC). - Lesnica, rye fields on northern part of village - Lesnica, gap of Lesnica, eastern slope, rye field, 640 m (both Eliáš jun. 2005 NI; Eliáš ml., Bull. Slov. Bot. Spoločn., 28: 77-79, 2006). - Vel'ký Lipník, northern slopes of Haligovce stones, $750 \mathrm{~m}$ (Čvančara 1975 BRA). 25. Mošovce (Textorisová 1924 SLO). - Turčianske Teplice, cereal fields (Margittai 1913 PR). 26b. Poprad, part Teplička, 700 m (Pax 1898 BP). - Spišská Nová Ves, fields,
460 m (Dietz 1878 BP; Ptačovský 1939 SAV). 26c. Ždiar (Domin 1935 PRC). 27a. Lednické Rovne, $1.2 \mathrm{~km}$ from Horenická Hôrka willage, wheat field (Mered'a sen., Bull. Slov. Bot. Spoločn, no. 22, p. 164, 2000). 27b. Bytča (Weber 1930 BRA). 28. Veličná (Hazslinsky s. d. BRA). - Rabča, oat field - Zubrohlava NNW, oat field - Zubrohlava SE, oat field (all data Májeková et Zaliberová 2006 SAV and Bull. Slov. Bot. Spoločn. 29:92-96, 2007). - Rabčice, 765 m (Zapałowicz 1880 sec. Migra, Oravské Múz. 3: 66, 1984). 29. Osturňa, oat field, $780 \mathrm{~m}$ - Osturňa, field above the Small Osturňa lake, $830 \mathrm{~m}$ (both Dvořák 1970 BRA, BRNM). - Majerka (Schill 1889 BP). - Lomnička (Vraný 1887 BRA). 30a. Prešov (Hazslinsky 1844 BP). 30c. Obručné, oat field - Lenartov, oat field - Gerlachov (all data Pospišil 1961 BMNM). Cigel'ka (Pospišil 1959 BRNM). - Bardejov (Berganský 1927 BRA). - Žalobín, basin of river Ol'ka (Králik, PhD. Thesis, 1977). 31. Runina, field, 550 m (Šourek 1957 PR; Černoch 1957 BRNM). - Ruské hammlett, 500 m (Soják 1962 PR).

Destroyed locality (not mapped): Lavkov (Truchlý 1893 BRA) - flooded by the Orava water reservoir.

Common data (not mapped): 9. Javorina, fields in the valleys (Holuby, Öst. Bot. Z., p. 296, 1865; Holuby, Let. Matice slov., no. 8, p. 18, 1871 and Holuby, Öst. Bot. Z., p. 56, 1871). 26a. the Liptov basin; frequently in cereals and beet crop (Pufflerová, MSc. Thesis, 1968). 